\title{
Impact of iceberg melting on Mediterranean thermohaline circulation during Heinrich events
}

\author{
F. J. Sierro, ${ }^{1}$ D. A. Hodell, ${ }^{2}$ J. H. Curtis, ${ }^{2}$ J. A. Flores, ${ }^{1}$ I. Reguera, ${ }^{1}$ \\ E. Colmenero-Hidalgo, ${ }^{1}$ M. A. Bárcena, ${ }^{1}$ J. O. Grimalt, ${ }^{3}$ I. Cacho, ${ }^{4}$ \\ J. Frigola, ${ }^{4}$ and M. Canals ${ }^{4}$ \\ Received 11 May 2004; revised 25 February 2005; accepted 28 March 2005; published 29 June 2005.
}

[1] Down-core samples of planktonic and benthic foraminifera were analyzed for oxygen and carbon isotopes in International Marine Past Global Changes Study (IMAGES) core MD99-2343 in order to study the interactions between climate change in the Northern Hemisphere and the western Mediterranean thermohaline circulation at times of Heinrich events (HE). Our results confirm the antiphase correlation between enhanced North Atlantic Deep Water formation and low ventilation in the Mediterranean. However, this study reveals that this antiphase relationship in deepwater formation between the North Atlantic and Mediterranean was interrupted during times of $\mathrm{HE}$ when the injection of large volumes of water from melting icebergs reached the entrance to the Mediterranean. These events, which lasted less than 1000 years, are represented by pronounced decreases in both planktonic $\delta^{18} \mathrm{O}$ and benthic $\delta^{13} \mathrm{C}$ signals. Lower salinities of Mediterranean surface water resulted in a slowdown of western Mediterranean deepwater overturn even though cold sea surface temperatures and drier climate should have resulted in enhanced deepwater formation.

Citation: Sierro, F. J., et al. (2005), Impact of iceberg melting on Mediterranean thermohaline circulation during Heinrich events, Paleoceanography, 20, PA2019, doi:10.1029/2004PA001051.

\section{Introduction}

[2] During the last glacial period evidence from Greenland ice cores and deep-sea sediments indicates that the climate in the Northern Hemisphere was subject to rapid coolings (stadials) and warmings (interstadials) normally referred to as Dansgaard-Oeschger (DO) millennial oscillations [Dansgaard et al., 1993; Bond and Lotti, 1995]. The deposition of layers of ice-rafted detritus (IRD) indicates that massive ice discharges (Heinrich events (HE)) occurred in the North Atlantic during some of the coldest stadials at the end of long-term cooling trends that include several DO oscillations [Heinrich, 1988; Bond et al., 1992, 1993; Broecker et al., 1992]. It has been postulated that the deposition of these major IRD layers resulted from catastrophic iceberg calving along the ice sheet margins of the North Atlantic [Bond et al., 1992; Broecker et al., 1992]. Although a large fraction of the IRD came from the Laurentide ice sheet, it has been suggested that at least in the northeast Atlantic, icebergs were calved first from the Eurasian ice sheets [Grousset et al., 2000]. Moreover, minor IRD events were found [Bond and Lotti, 1995] associated

\footnotetext{
${ }^{1}$ Department of Geology, University of Salamanca, Salamanca, Spain. ${ }^{2}$ Department of Geological Sciences, University of Florida, Gainesville, Florida, USA.

${ }^{3}$ Department of Environmental Chemistry, Institute of Chemical and Environmental Research, Barcelona, Spain.

${ }^{4}$ Department of Stratigraphy, Paleontology and Marine Geosciences, University of Barcelona, Barcelona, Spain.
}

Copyright 2005 by the American Geophysical Union. 0883-8305/05/2004PA001051\$12.00 with all DO climatic oscillations, demonstrating that IRD events occurred much more frequently than previously thought, although they were recorded only in cores taken in the vicinity of the ice sheet margins. Iceberg melting during HE affected the hydrology of the North Atlantic Ocean, particularly the latitudes between $40^{\circ} \mathrm{N}$ and $55^{\circ} \mathrm{N}$ [Ruddiman, 1977] where the major IRD layers were deposited and planktonic foraminifera show pronounced decreases in $\delta^{18} \mathrm{O}$ values, indicating the presence of meltwater [Heinrich, 1988; Grousset et al., 1993; Cortijo et al., 1997; Elliot et al., 1998, 2001].

[3] The injection of large volumes of freshwater slowed the formation of North Atlantic Deep Water (NADW) and reduced northerly advection of the warm subtropical waters that would normally heat the atmosphere of Greenland and western Europe [Broecker et al., 1985, 1992; Bond et al., 1992, 1993; Vidal et al., 1997; Elliot et al., 2002]. The influence of icebergs and meltwater may have extended southward and eastward into the subtropics and offshore Portugal [Shackleton et al., 2000; Schönfeld and Zahn, 2000; Bard et al., 2000; Schönfeld et al., 2003]. Here we present oxygen and carbon isotope data of foraminifera from the deep northern margin of the Balearic Islands in the western Mediterranean Sea suggesting that the meltwater released by icebergs from the Laurentide or Eurasian ice sheets had a profound effect on Mediterranean surface salinity and thermohaline circulation at times of HE.

[4] Previous data [Cacho et al., 2000] have shown during glacial periods that Mediterranean thermohaline circulation was closely coupled to abrupt climate changes in the North Atlantic and subpolar regions. The Mediterranean surface waters cooled and sank in response to the decreasing SST of 
northeast Atlantic surface waters and the resulting cold winds that reached southern Europe [Cacho et al., 2000]. However, our study indicates that the atmospheric teleconnection with the high latitudes that governed the Mediterranean deepwater circulation during the last glaciation [Cacho et al., 2000] was overcome at times of HE by a direct hydrologic connection triggered by the massive release of icebergs in the North Atlantic; the influence of those icebergs reached the entrance to the Mediterranean and caused a significant slowdown of deepwater Mediterranean circulation. Because Mediterranean outflow adds a significant amount of salt to the North Atlantic and the formation of NADW is primarily controlled by changes in SST and salinity of surface waters, past variations in the Mediterranean salt export may have had in turn a significant impact on Atlantic thermohaline circulation and SST [Reid, 1979; Johnson, 1997]. However, the magnitude of this effect has recently been estimated by Rahmstorf [1998] to have been relatively small, although it could have been more pronounced during glacial times when the rate of NADW production was lower than today.

[5] Over the past million years, small changes in the Mediterranean water budget had a profound impact on thermohaline circulation within the basin, as evidenced by the formation of sapropels in the eastern basin and organicrich layers in the western Mediterranean [Rossignol-Strick et al., 1982; Hilgen, 1991; Comas et al., 1996]. Many studies have addressed the relationship between enhanced freshwater input into the basin at times of summer insolation maxima in the Northern Hemisphere and the formation of sapropels (see Rohling [1994] for a review], but little is known about the impact that changes in the inflowing Atlantic waters had on Mediterranean thermohaline circulation.

\section{Present Western Mediterranean Hydrology}

[6] The excess of evaporation over precipitation and runoff in the Mediterranean causes Atlantic surface waters to enter the Mediterranean and deep waters to flow outward into the Atlantic through the Strait of Gibraltar at a depth of approximately $400 \mathrm{~m}$ [Bryden et al., 1994]. At the Gibraltar Strait Atlantic surface waters are transformed to form Modified Atlantic Waters (MAW) by mixing with outflowing Mediterranean intermediate waters [Millot, 1999] (see Figure 1). The MAW is progressively modified by continuous evaporation along their path to the eastern Mediterranean mainly along the North African coast. Well inside the Mediterranean, some anticyclonic eddies detach from the MAW as it flows along the North African coast to spread toward the Balearic Islands [Millot, 1999] (Figure 1). The MAW divides into two branches near the Sicilian strait, one entering the eastern Mediterranean basin, while the other continues northwestward along the southern coasts of Italy, France, and Spain to form the so-called Northern Current. In the Gulf of Lions, surface waters from the Northern Current are swept away southward by the northwesterlies, leading to the formation of the Northern Balearic Front that separates these northern cold waters from the eddies originated in the MAW that flow directly from the Strait of Gibraltar [Millot,

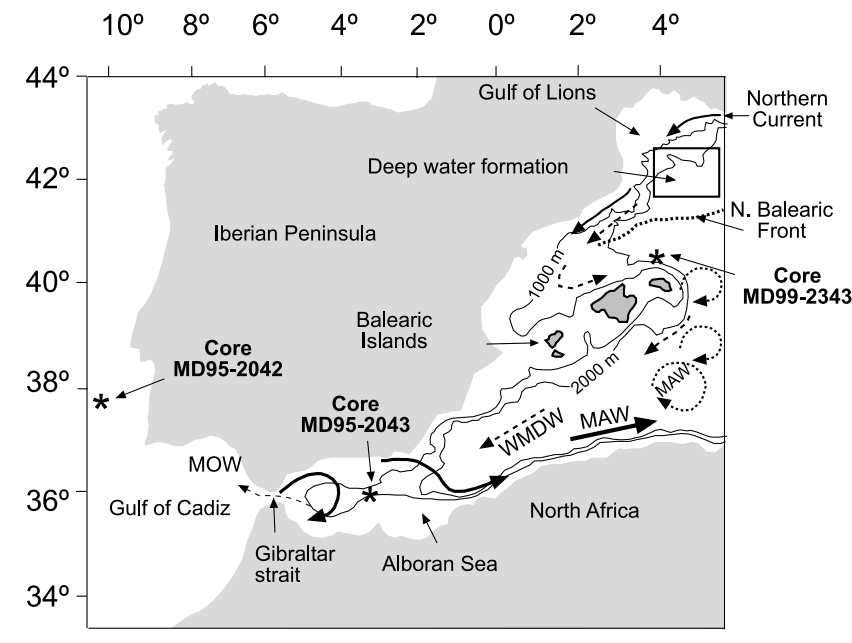

Figure 1. Map of the western Mediterranean with the location of cores MD99-2343 and MD95-2043. The location of Core MD95-2042 is also shown. Arrows represent the main oceanographic currents. The black line represents Modified Atlantic Waters (MAW) flowing from the Atlantic toward the western Mediterranean. Dotted lines correspond to eddies detached from the MAW as it moves along the African coast. Dashed line shows the western Mediterranean Deep Water (WMDW) flowing from the Gulf of Lions toward the Strait of Gibraltar.

1999] (Figure 1). Levantine Intermediate Water (LIW) is warm and salty because it originates in the eastern Mediterranean and flows toward the west between 200 and $600 \mathrm{~m}$ depth, mainly across the Sardinian margin [Millot, 1999]. Western Mediterranean Deep Water (WMDW) is formed in the Gulf of Lions, north of the Balearic Islands (Figure 1), especially during particularly cold and windy winters when surface waters sink to reach the bottom of the basin [MEDOC Group, 1970; Lacombe et al., 1985]. Deepwater formation is triggered by the cool, northwesterly winds (tramontana and mistral) reaching the northern Gulf of Lions during winter, which cool surface waters and increase their density. However, the high density needed for these waters to sink is only reached when surface waters contain enough salt. At present, the excess of evaporation over total freshwater input results in salinities over 38\% in surface waters in the Gulf of Lions [MEDOC Group, 1970; Lacombe et al., 1985]. WMDW flows toward the Strait of Gibraltar, following a path along the western continental margin of the Iberian Peninsula [Millot, 1999], and forms the sedimentary drift [Velasco et al., 1996] where core MD99-2343 was retrieved (Figure 1).

\section{Material and Methods}

[7] Core MD99-2343 $\left(40^{\circ} 29.84^{\prime} \mathrm{N} ; 4^{\circ} 1.69^{\prime} \mathrm{E}\right)$ was recovered from a water depth of $2391 \mathrm{~m}$ north of Menorca (northwestern Mediterranean) during cruise IMAGES V of the R/V Marion Dufresne (Figure 1). The core site is located on a sediment drift, which was formed along the deep northeastern margin of Menorca [Velasco et al., 1996] 
because of the Mediterranean deepwater mass originating in the Gulf of Lions [MEDOC Group, 1970; Lacombe et al., 1985]. This core was taken in a suitable position for monitoring past changes in both WMDW as it flows toward the Atlantic and MAW as it spreads into the western Mediterranean.

[8] Core MD99-2343 is $32.44 \mathrm{~m}$ long and was sampled every 4 to $6 \mathrm{~cm}$ except in the intervals corresponding to the HE where samples were taken every $2 \mathrm{~cm}$. On the basis of the age model discussed in the next section, this sampling corresponds to a temporal resolution of one sample every 100 to 200 years in the former case and 30 to 60 years during HE. Samples for isotope analyses and foraminiferal countings were washed over a $63-\mu \mathrm{m}$ sieve and residues were dried and dry sieved again using a $150-\mu \mathrm{m}$ sieve. The $>150-\mu \mathrm{m}$ fraction was then split as many times as necessary to obtain an aliquot of approximately 400 specimens of planktonic foraminifera. Samples were counted to calculate the relative percentages of the major planktonic foraminiferal taxa. To study the coccolithophore assemblages, slides were prepared following the technique of Flores and Sierro [1997]. A total of around 500 coccoliths were counted to obtain the percent abundance of selected species and/or morphotypes.

[9] Approximately 5 to 10 specimens of Globigerina bulloides from the 300- to 350- $\mu \mathrm{m}$-size fraction and 4 to 8 specimens of Cibicidoides pachydermus were picked to measure oxygen and carbon isotope ratios. In addition, 5 to 10 specimens of Neogloboquadrina pachyderma dextral (d) and Neogloboquadrina pachyderma sinistral (s) from the 250- to $350-\mu \mathrm{m}$ and 212- to 350- $\mu \mathrm{m}$-size fractions, respectively, were picked in the intervals of HE. Additional isotope analyses were also performed on Globigerina bulloides from Core MD95-2043 located in the Alboran Sea, previously analyzed by Cacho et al. [1999], in order to increase the resolution of the isotope record.

[10] Foraminiferal tests were soaked in $15 \% \mathrm{H}_{2} \mathrm{O}_{2}$ to remove organic matter and cleaned sonically in methanol to remove fine-grained particles. The foraminiferal calcite was loaded into individual reaction vessels and each sample was reacted with three drops of $\mathrm{H}_{3} \mathrm{PO}_{4}$ (specific gravity = 1.92) using a Finnigan MAT Kiel III carbonate preparation device. Isotope ratios were measured online using a Finnigan MAT 252 mass spectrometer. Analytical precision was estimated to be $\pm 0.08 \%$ for $\delta^{18} \mathrm{O}$ and $\pm 0.03 \%$ for $\delta^{13} \mathrm{C}$ (expressed as \pm 1 standard deviation) by measuring 8 standards (NBS-19) with each carousel containing 38 samples. All isotope results are reported in standard delta notation relative to V-PDB [Coplen, 1996].

\section{Age Model}

[11] The chronology of core MD99-2343 is constrained by four AMS ${ }^{14} \mathrm{C}$ dates of mixed planktonic foraminifera from the upper part of the core and the correlation of the $G$. bulloides $\delta^{18} \mathrm{O}$ signal with the GISP2 oxygen isotope record [Grootes and Stuiver, 1997]. Previous studies have shown that oxygen isotope records in the Mediterranean are mainly controlled by variations in SST that are nearly synchronous with air temperature changes over Greenland [Cacho et al.,
Table 1. Age Model for Core MD99-2343 ${ }^{\mathrm{a}}$

\begin{tabular}{lccr}
\hline $\begin{array}{c}\text { Isotope Event/Radiocarbon } \\
\text { Sample }\end{array}$ & $\begin{array}{c}\text { Depth, cm } \\
{ }^{14} \mathrm{C}, \\
\text { year B.P. }\end{array}$ & $\begin{array}{r}\text { Calendar } \\
\text { Years }\end{array}$ \\
\hline AMS $^{14} \mathrm{C}$ & 28 & $790( \pm 40)$ & 388 \\
AMS $^{14} \mathrm{C}$ & 118 & $3,390( \pm 50)$ & 3,215 \\
AMS $^{14} \mathrm{C}$ & 238 & $6,210( \pm 50)$ & 6,595 \\
Top YD & 364 & & 11,573 \\
Maximum YD & 414 & & 12,590 \\
Base Bolling-Allerod & 490 & & 14,750 \\
AMS ${ }^{14}$ C & 604 & $14,550( \pm 110)$ & 16,805 \\
Base interstadial 3 & 954 & & 27,736 \\
Base interstadial 4 & 994 & & 29,000 \\
Base warming event & 1,060 & & 30,619 \\
Base interstadial 5 & 1,110 & & 32,300 \\
Base interstadial 6 & 1,144 & & 33,587 \\
Base interstadial 7 & 1,190 & & 35,400 \\
Base interstadial 8 & 1,260 & & 38,432 \\
Base interstadial 10 & 1,360 & & 41,172 \\
Base interstadial 11 & 1,410 & & 45,360 \\
Base interstadial 12 & 1,520 & & 47,146 \\
Base interstadial 13 & 1,584 & & \\
\hline
\end{tabular}

${ }^{\mathrm{a} C}$ Calendar years were based on calibration of the radiocarbon dates using the program Calib 4.4 [Stuiver et al., 1998]. Ages of isotope events in Greenland Ice Core GISP2 [Meese et al., 1997] were used to calibrate isotope events in core MD99-2343. AMS is accelerator mass spectrometry; YD is Younger Dryas.

1999]. AMS ${ }^{14} \mathrm{C}$ analyses were performed at Geochron Laboratories (Cambridge, Massachusetts, USA) and the ages were calibrated using the standard marine correction of 400 years and the Calib 4.4 program [Stuiver et al., 1998]. For the oxygen isotope correlation, we selected as reference levels the ages of abrupt warming events that occurred at the base of the main interstadials, which are well defined in the Mediterranean isotope record. The GISP2 age model was established by annual layer counting in the ice core [Meese et al., 1997]. All reference depth levels used to establish the chronology are given in Table 1. The ages of the HE were not used in construction of the age model.

\section{Results}

[12] The $\delta^{18} \mathrm{O}$ record of G. bulloides exhibits pronounced millennial-scale changes throughout isotope stages 3 and 2 (Figure 2) that resemble stadial-to-interstadial changes in the Greenland $\delta^{18} \mathrm{O}$ ice record [Grootes and Stuiver, 1997]. High $\delta^{18} \mathrm{O}$ values in $G$. bulloides are correlated with stadials, while low $\delta^{18} \mathrm{O}$ values occur at interstadials.

[13] Four incursions of the polar water species Neogloboquadrina pachyderma (s) were identified at 16, 24, 30 and 39 kyr (Figure 2) which correlate with HE1 to HE4 in the North Atlantic because this species was only present in the Mediterranean and adjacent NE Atlantic during these events [Cacho et al., 1999; Pérez-Folgado et al., 2003]. Changes in abundance of the coccolithophore Emiliania huxleyi $(>4 \mu \mathrm{m})$, which has been reported to be a cold water species in the NE Atlantic and Mediterranean [ColmeneroHidalgo et al., 2002, 2004], were also used to correlate the $\delta^{18} \mathrm{O}$ record of $G$. bulloides with millennial oscillations in Greenland. This allowed us to identify HE5, where $N$. pachyderma (s) is absent.

[14] The early and late phases of the HE are associated with increases in $G$. bulloides $\delta^{18} \mathrm{O}$; however, prominent 


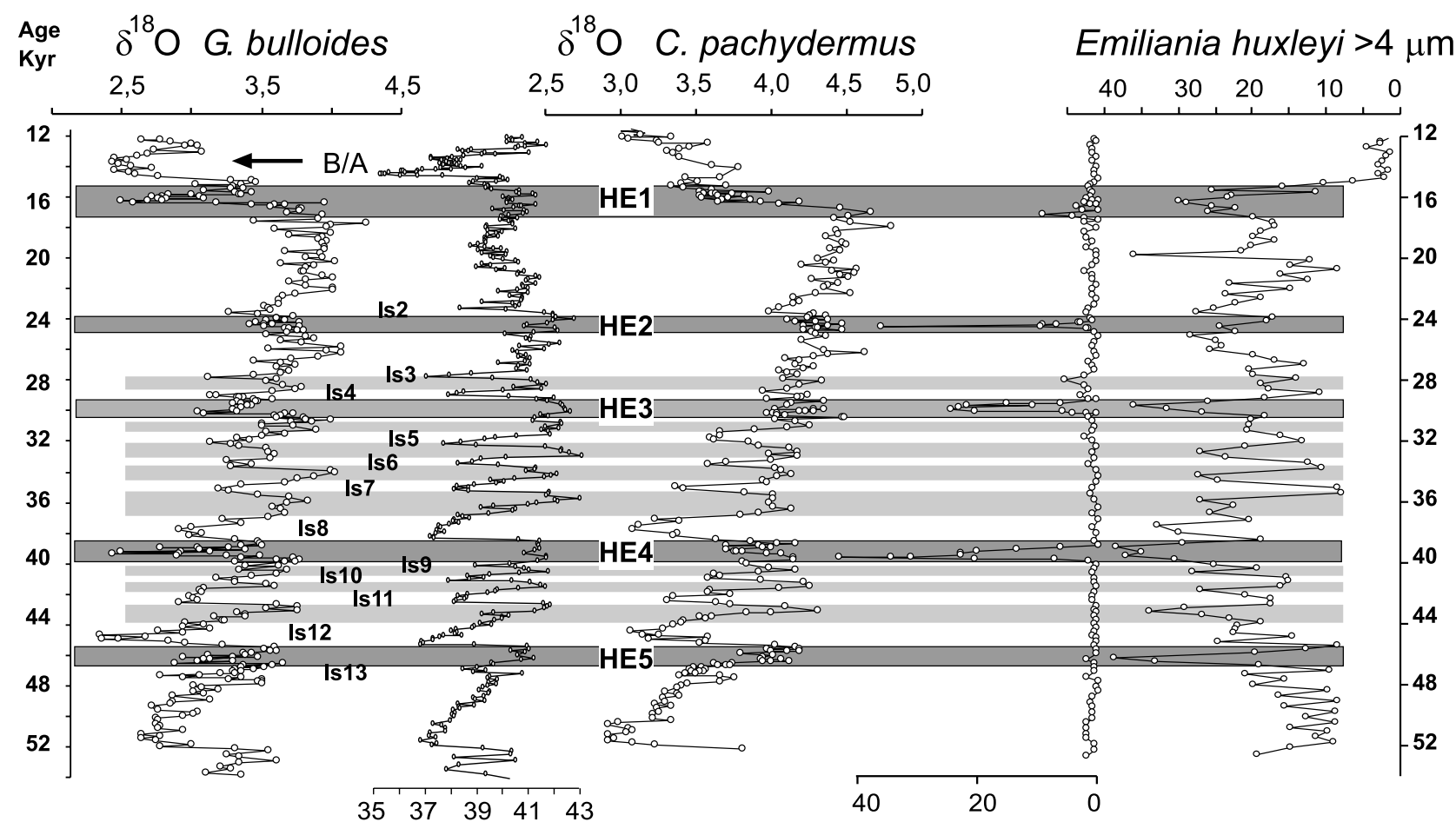

$\delta^{18} \mathrm{O}$ ice GISP2

$\%$ N. pachyderma (s)

Figure 2. Oxygen isotope records of Globigerina bulloides and Cibicidoides pachydermus versus age from core MD99-2343 compared with the relative abundance of Neogloboquadrina pachyderma (s) and Emiliania huxleyi $>4 \mu \mathrm{m}$ and the oxygen isotope record from the Greenland Ice Core Greenland Ice Sheet Project 2 (GISP2) [Grootes and Stuiver, 1997]. Dark shading designates the Heinrich events (HE), whereas lighter shading represents stadials that are unrelated to HE. Millennial-scale variability in the Globigerina bulloides $\delta^{18} \mathrm{O}$ record reflects changes in sea surface temperature and/or changes in the Mediterranean hydrological budget, but the strong depletions that occur during each of the $\mathrm{HE}$ are related to the input of icebergs or iceberg-derived meltwaters from the Atlantic. $\mathrm{B} / \mathrm{A}$ is Bølling/Allerød.

decreases in oxygen isotope values are observed in the middle of these events. These oxygen isotope minima were particularly pronounced during HE1 and HE4, when the magnitude of the change was about $-1.6 \%$ and $-1.4 \%$, respectively. The $\delta^{18} \mathrm{O}$ excursion during HE1 was especially abrupt and is marked by a prominent depletion event between 16.2 and 15.7 kyr. During HE5 a small decrease in planktonic $\delta^{18} \mathrm{O}$ values is clearly discernible (Figure 2).

[15] In order to estimate the change in $\delta^{18} \mathrm{O}$ of surface waters during HE, the planktonic $\delta^{18} \mathrm{O}$ data were corrected for changes in ice volume [Lea et al., 2002] and SST by assuming a $\delta^{18} \mathrm{O}$ change of $0.23 \%$ per degree centigrade [Kim and O'Neil, 1997]. Temperature corrections were made using average annual SSTs estimated by Reguera [2004] through the modern analog technique. Significant negative anomalies in the $\delta^{18} \mathrm{O}$ of surface water ranging from $-0.6 \%$ to $-1.2 \%$ occurred in all $\mathrm{HE}$ that are discernible from the decreases observed during interstadial events, such as interstadials 12 and 8 (Figure 3).

[16] Similar $\delta^{18} \mathrm{O}$ oscillations were observed in the Cibicidoides pachydermus isotope record, with higher values during stadials and lower values in the interstadials. How- ever, unlike the $G$. bulloides $\delta^{18} \mathrm{O}$ record, the benthic foraminifera do not display the pronounced depletions observed within the HE (Figure 2); only small negative anomalies may be seen in some of the HE (i.e., HE4 and HE5).

[17] The C. pachydermus $\delta^{13} \mathrm{C}$ record (Figure 3) displays fluctuations of about $0.8 \%$ in response to stadial-interstadial oscillations. High $\delta^{13} \mathrm{C}$ values in benthic foraminifera are consistently linked to stadial events, whereas low $\delta^{13} \mathrm{C}$ in C. pachydermus typically occurred during interstadial periods (Figure 3).

[18] Oxygen and carbon isotope values were also measured in Neogloboquadrina pachyderma (d) and Neogloboquadrina pachyderma (s) for all $\mathrm{HE}$ where these species were present (Figures 4 and 5). The oxygen isotope values of $N$. pachyderma (d) are similar to those of G. bulloides and are consistently lower for all HE (Figures 4 and 5). $N$. pachyderma (s), however, shows oxygen isotope decreases in HE1 and HE4 but not in HE3 and HE2, although very few data are available for the last interval.

[19] To test whether the oxygen isotope pattern we observed in the Balearic Sea is also present in other 


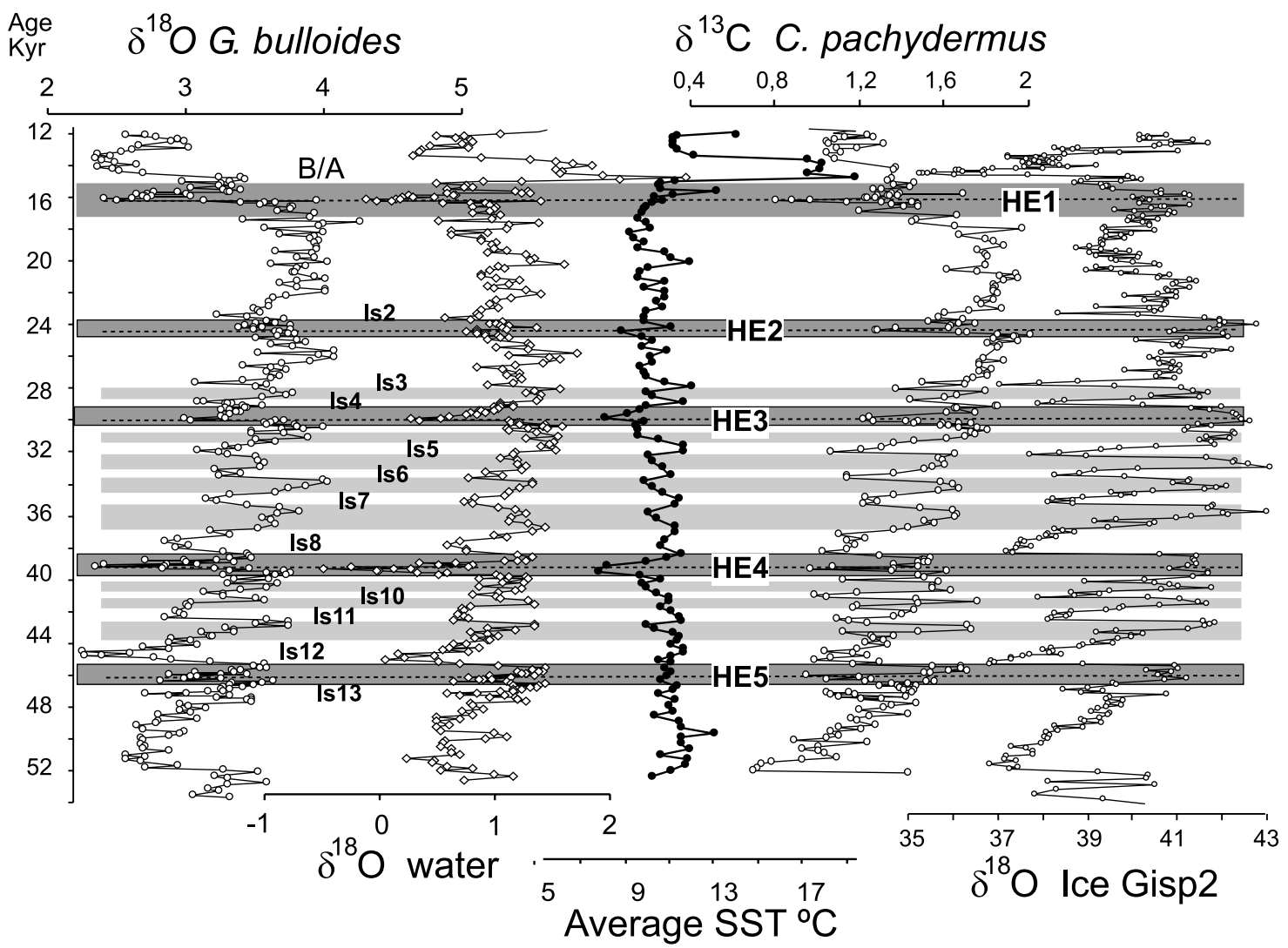

Figure 3. Comparison of $\delta^{18} \mathrm{O}$ record of Globigerina bulloides, $\delta^{13} \mathrm{C}$ of Cibicidoides pachydermus, calculated $\delta^{18} \mathrm{O}$ for Mediterranean surface waters, average annual sea surface temperature (SST), and the $\delta^{18} \mathrm{O}$ of the Greenland Ice Core GISP2 [Grootes and Stuiver, 1997]. Dark shading designates the HE, whereas lighter shading represents stadials that are unrelated to HE. Dashed horizontal lines outline the minimum $\delta^{13} \mathrm{C}$ values in Cibicidoides pachydermus during the HE. All stadial events correspond with high $\delta^{13} \mathrm{C}$ values in Cibicidoides pachydermus with the exception of the $\mathrm{HE}$ where prominent depletions are observed. B/A is Bølling/Allerød.

locations of the western Mediterranean, we analyzed new samples from core MD95-2043, previously studied by Cacho et al. [1999]. We analyzed the core at higher resolution, especially at the intervals of HE defined by the peaks in abundance of $N$. pachyderma (s). Similar to core MD99-2343, all $\mathrm{HE}$ are associated with decreasing $\delta^{18} \mathrm{O}$ values in G. bulloides (Figure 6). The $\delta^{18} \mathrm{O}$ of surface water was calculated following the above mentioned method but using the alkenone-derived temperature record published by Cacho et al. [1999]. Significant depletions in ${ }^{18} \mathrm{O}$ of surface waters similar to those seen in the Balearic Islands occurred in all HE.

\section{Interpretation and Discussion}

\subsection{Mediterranean Oxygen Isotope Excursions During Heinrich Events}

[20] As previously inferred from other cores from the western Mediterranean and northeast Atlantic, the $\delta^{18} \mathrm{O}$ fluctuations observed in G. bulloides in MD99-2343 are driven mainly by changes in SST [Cacho et al., 1999; Shackleton et al., 2000; Skinner and Shackleton, 2003].
Variations in westernmost Mediterranean SST of about $2^{\circ}$ to $4^{\circ} \mathrm{C}$ correlate with millennial-scale climate variability (i.e., Dansgaard-Oeschger events) in Greenland [Cacho et al., 1999; Pérez-Folgado et al., 2003; Martrat et al., 2004].

[21] Lower $\delta^{18} \mathrm{O}$ values of $G$. bulloides during interstadials are related to warmer surface waters and/or to depleted ${ }^{18} \mathrm{O}$ values associated with a less negative freshwater balance prevailing in the western Mediterranean during those times [Cacho et al., 2000; Sánchez-Goñi et al., 2002]. In contrast, cooler SSTs and a more negative freshwater balance during stadials would result in higher oxygen isotope values.

[22] If the pattern of high $\delta^{18} \mathrm{O}$ values during stadials and low $\delta^{18} \mathrm{O}$ values during interstadials is consistent with climate variability in Greenland, the pronounced ${ }^{18} \mathrm{O}$ depletions observed within the HE are totally unexpected. These depletions occurred at times when SSTs in the Mediterranean were very cold, with values between $7^{\circ}$ and $10^{\circ} \mathrm{C}$ in the Alboran Sea [Cacho et al., 1999; Pérez-Folgado et al., 2003], and climate on land was extremely dry [SánchezGoñi et al., 2002; Combourieu-Nebout et al., 2002; Bartov et al., 2003]. These environmental conditions are in com- 

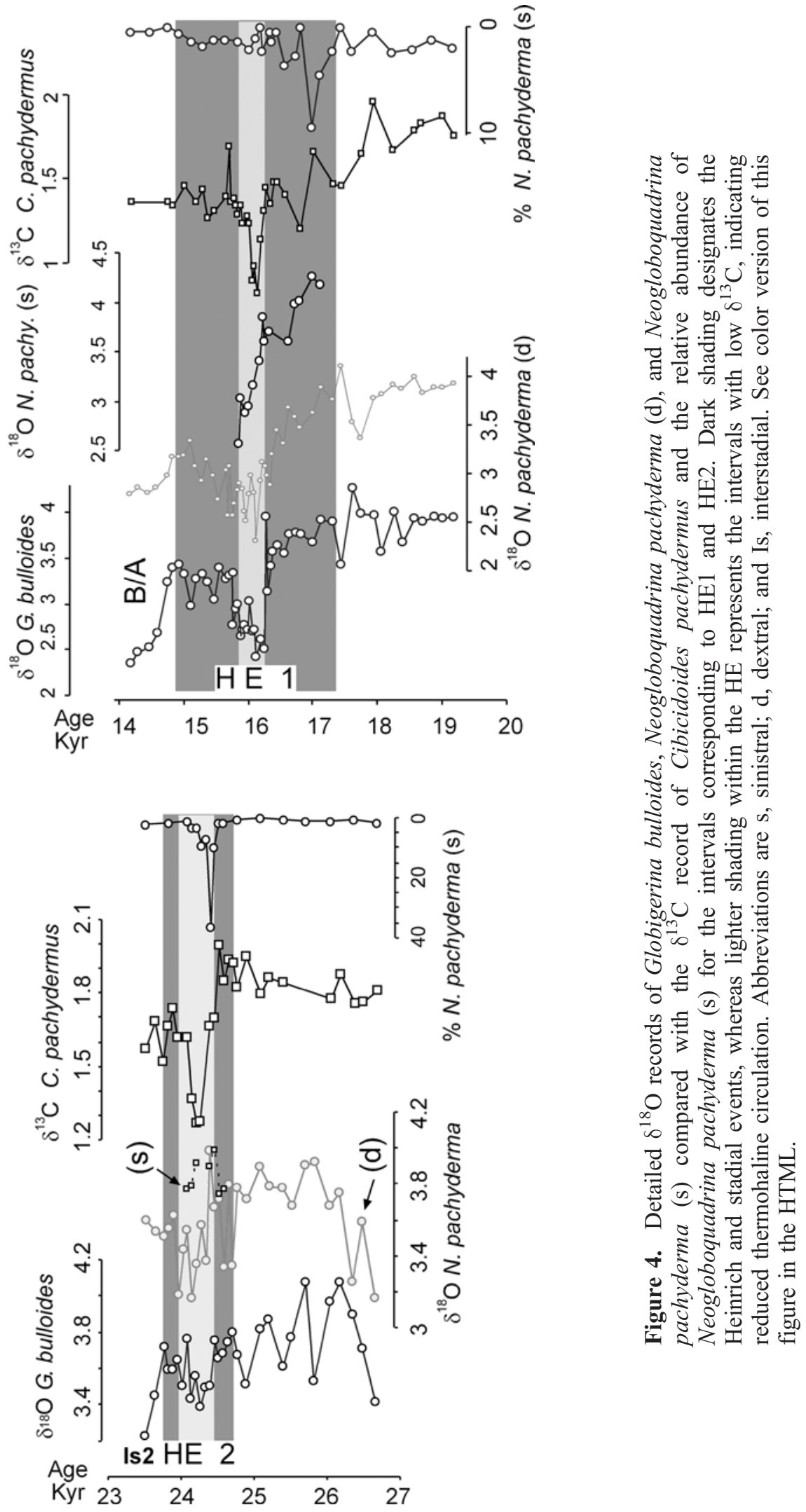

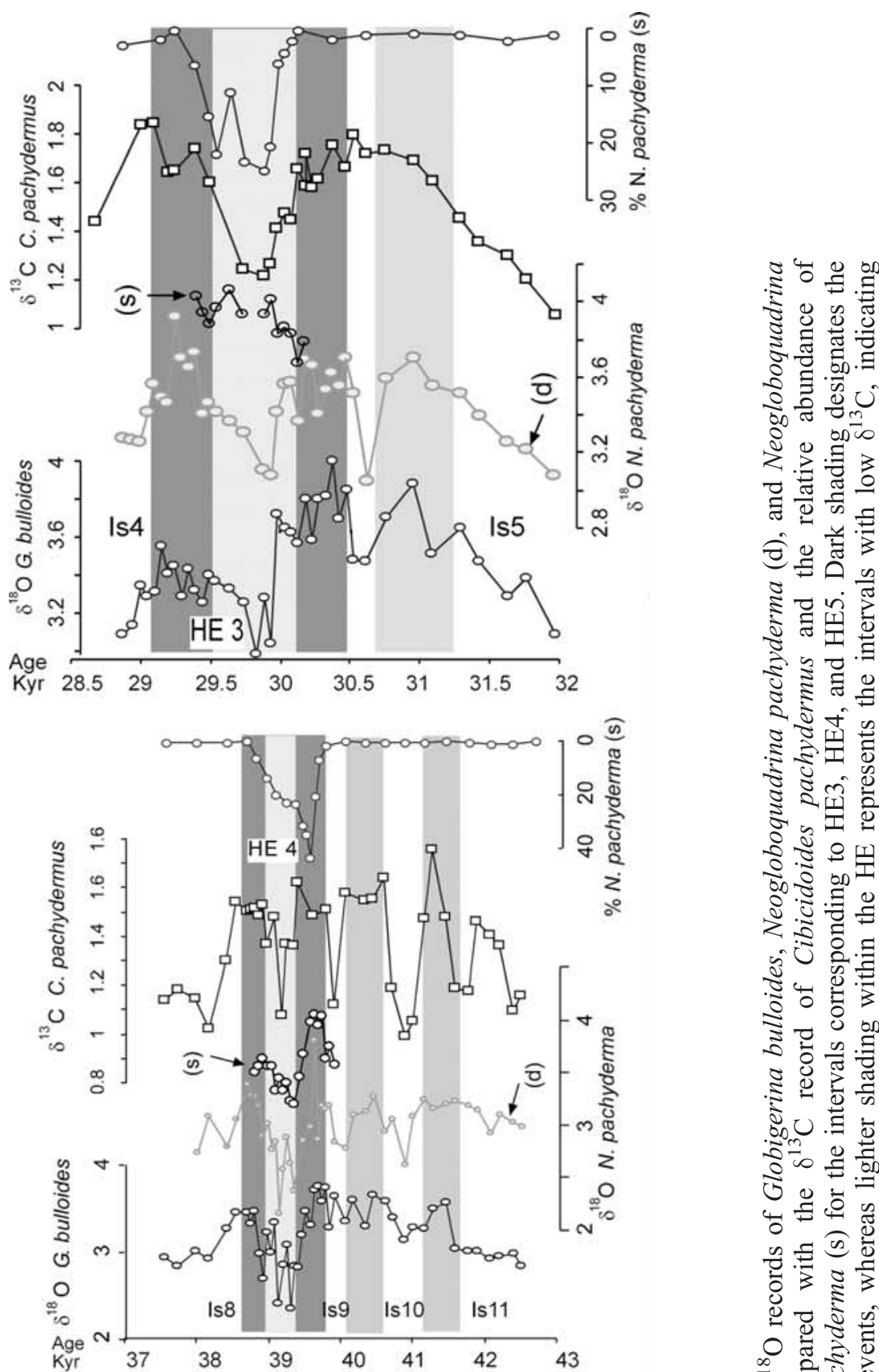

正哇

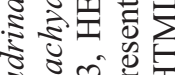

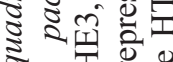

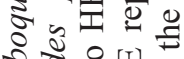

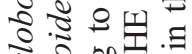

\&.: $: \cong$

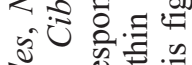

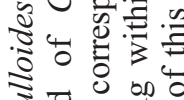

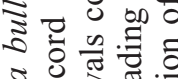

원

ठั.

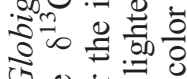

岁

号司的

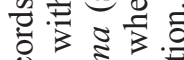

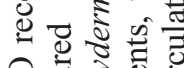

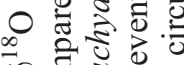
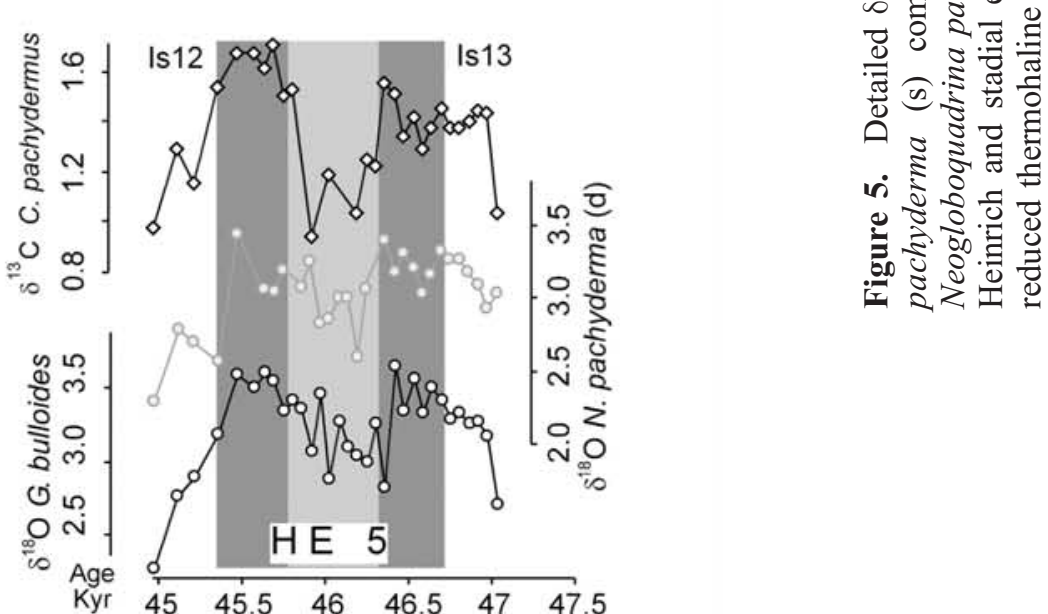

7 of 13 


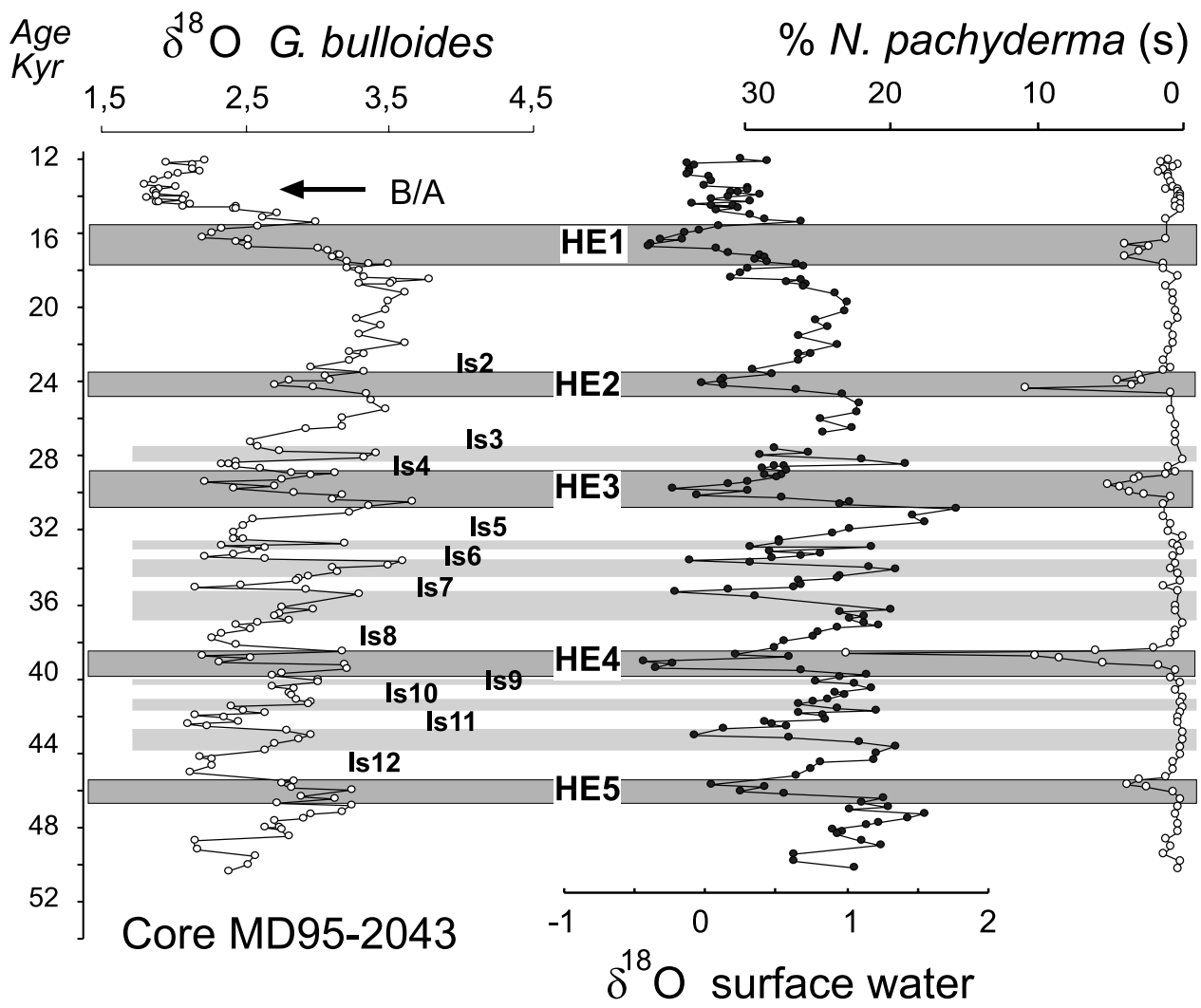

Figure 6. $\delta^{18} \mathrm{O}$ record of Globigerina bulloides versus the calculated $\delta^{18} \mathrm{O}$ of surface waters and percent abundance of Neogloboquadrina pachyderma (s) from core MD95-2043 in the Alboran Sea. Oxygen isotopes were measured every $5 \mathrm{~cm}$ to complement previous, lower-resolution $\delta^{18} \mathrm{O}$ data published by Cacho et al. [1999]. Percent abundance of Neogloboquadrina pachyderma (s) is after Cacho et al. [1999]. Dark shading designates the HE, whereas lighter shading represents stadials that are unrelated to the HE. B/A is Bølling/Allerød.

plete contradiction to the lowering of the $\delta^{18} \mathrm{O}$ values of surface waters estimated in our study (Figure 3). As reported by Rohling [1999], the average $\delta^{18} \mathrm{O}$ of Mediterranean waters depends on the relative contribution of water sources including the $\delta^{18} \mathrm{O}$ of Atlantic inflow, the isotope composition of evaporating water, and the $\delta^{18} \mathrm{O}$ values of precipitation, runoff, and Black Sea outflow. During HE, freshwater flux into the Mediterranean should be lower owing to reduced precipitation and runoff as indicated by marine [Sánchez-Goñi et al., 2002; Combourieu-Nebout et al., 2002], lacustrine [Bartov et al., 2003] and speleothem records from southern France and Israel [Genti et al., 2003]. As a result, we conclude that sharp decreases in the $\delta^{18} \mathrm{O}$ of Atlantic inflow are the most likely cause for these oxygen isotope depletions. The injection of a large volume of freshwater derived from melting icebergs in the North Atlantic could decrease the $\delta^{18} \mathrm{O}$ of Atlantic surface waters entering the Mediterranean.

[23] A large proportion of iceberg meltwater in the Atlantic inflow during HE should have had a greater impact on the $\delta^{18} \mathrm{O}$ of Mediterranean surface water than its salinity. If this effect is ignored, salinity can be estimated using linear relationships between $\delta^{18} \mathrm{O}$ and salinity calculated for the Atlantic and Mediterranean [Craig and Gordon, 1965;
Pierre, 1999]. The anomalies would correspond to decreases in the salinity of western Mediterranean surface waters of between 2 and 4\%.

[24] If surface waters in the Mediterranean were depleted in ${ }^{18} \mathrm{O}$ during the $\mathrm{HE}$ owing to increased meltwater in the Atlantic inflow, then the isotope records of all species living in surface waters should record this signal. The $\delta^{18} \mathrm{O}$ in $N$. pachyderma (d) displays similar depletions during all $\mathrm{HE}$, while $N$. pachyderma (s) shows oxygen isotope decreases in HE1 and HE4, but not in HE3 and HE2 (Figures 4 and 5). The oxygen isotope values of $N$. pachyderma (s) are always greater than those of $N$. pachyderma (d), suggesting this species lived in colder water and probably at greater depth.

[25] Because of increased iceberg discharge during HE, the $\delta^{18} \mathrm{O}$ of North Atlantic surface waters decreased in response to the injection of large volumes of meltwater and this decrease was greater in the region of the IRD belt between $40^{\circ}$ and $50^{\circ} \mathrm{N}$, where most icebergs melted and maximum concentrations of IRD have been found [Ruddiman, 1977; Grousset et al., 1993]. Within HE4, negative isotope anomalies (not corrected for temperature) exceeding $1 \%$ are only found in a narrow band between $43^{\circ} \mathrm{N}$ and $50^{\circ} \mathrm{N}$ in the North Atlantic corresponding to a reduction in salinity by 2 to $3 \%$ [Cortijo et al., 1997]. In 
contrast, the anomalies are smaller outside this region, averaging between $0.5 \%$ and $0.1 \%$ [Cortijo et al., 1997]. The Mediterranean isotope excursion observed in HE4 lies within the range of the isotope anomalies found in the IRD belt. New cores taken along the Portuguese margin also reveal $\delta^{18} \mathrm{O}$ anomalies of between 0.5 and $1.5 \%$ for HE4 [Shackleton et al., 2000; Schönfeld and Zahn, 2000; Schönfeld et al., 2003], indicating that the effect extended eastward and southward across the North Atlantic. The magnitude of the isotope excursion is highly variable, however, and may have depended on the route the icebergs followed on their way south. Smaller anomalies might be expected in cores retrieved from localities closer to the coast as opposed to offshore [Schönfeld et al., 2003]. With the exception of HE4, the oxygen isotope depletions in MD99-2343 are greater than those observed on the northern part of the Portuguese margin [core MD95-2040, Schönfeld et al., 2003], and they are significantly larger than the anomalies recorded in the southern locations [Shackleton et al., 2000; Schönfeld and Zahn, 2000] near the entrance to the Mediterranean. The patterns of IRD distributions and $\delta^{18} \mathrm{O}$ anomalies in the North Atlantic [Grousset et al., 1993; Cortijo et al., 1997; Shackleton et al., 2000; de Abreu et al., 2003; Schönfeld et al., 2003] indicate that icebergs from the main IRD belt between $40^{\circ}$ and $50^{\circ} \mathrm{N}$ were deflected toward the south, following the eastern boundary current toward the entrance to the Mediterranean.

[26] The $\delta^{18} \mathrm{O}$ anomalies reported in this study could also be related to direct freshwater discharges to the Mediterranean. It has been postulated that meltwater from lakes dammed by the Scandinavian ice sheet flowed to the Volga River and to the Black Sea [Mangerud et al., 2004], with possible inflow into the Mediterranean. However, no evidence of meltwater input has so far been found in the Eastern Mediterranean. Rhone River discharge related to the Eurasian ice sheet margins and the Alps could have been another source of freshwater to the Northwest Mediterranean during the last glacial period, although, high-resolution oxygen isotope records from the Gulf of Lions, in the region of the Rhone prodelta, show no significant ${ }^{18} \mathrm{O}$ depletion in HE1 and HE2 (F. J. Sierro, unpublished data, 2004, core MD99-2348).

[27] The oxygen isotope records from sediment cores in the Gulf of Cadiz, at the entrance to the Mediterranean, show ${ }^{18} \mathrm{O}$ depletions in HE1 and HE4 but not in HE2 and HE3 [Mulder et al., 2002; Colmenero-Hidalgo et al., 2004]. However, the new G. bulloides $\delta^{18} \mathrm{O}$ record in the Alboran Sea (Figure 6, core MD95-2043) located on the Mediterranean side of the Strait of Gibraltar in a region largely influenced by Atlantic surface waters clearly reveals prominent $\delta^{18} \mathrm{O}$ lowerings during all HE. The same pattern is seen at ODP site 976 located in the westernmost Mediterranean, very close to the Strait of Gibraltar [CombourieuNebout et al., 2002]. An apparent contradiction thus emerges between the different observations of oxygen isotopic depletions on either side of the Strait of Gibraltar. This contradiction can be explained if the route followed by the icebergs or iceberg-derived freshwater in the Gulf of Cadiz was north of the locations studied by Mulder et al. [2002] and Colmenero-Hidalgo et al. [2004]. This would have left no evidence at their sites. The amplification of the negative oxygen isotopic anomalies inside the Mediterranean can also be related with reduced mixing between the Atlantic inflow and the Mediterranean intermediate waters at the Strait of Gibraltar during the HE. This would allow the Atlantic water, which normally increased the $\delta^{18} \mathrm{O}$ values at the Strait, to enter the Mediterranean with no significant modification of its isotopic signature. All these observations are consistent with the Atlantic origin of the freshwater anomalies in the Alboran Sea and carried by the MAW to the Balearic Islands. There, it would have rapidly disappeared in the Gulf of Lions, where the MAW mixed intensively with intermediate and deep Mediterranean waters, resulting in loss of typical Atlantic isotope depleted values.

[28] Today, two water layers with differing oxygen isotope values are present in the Mediterranean: (1) Atlantic inflow (MAW), with $\delta^{18} \mathrm{O}$ values between $0.7 \%$ and $1.2 \%$ extending over the western Mediterranean, and (2) LIW and WMDW, with $\delta^{18} \mathrm{O}$ values between $1.5 \%$ and $1.6 \%$ that typically reflect the isotope composition of surface waters sinking in the eastern Mediterranean [Pierre, 1999]. The oxygen isotope values of waters of Atlantic origin gradually increase from $0.7 \%$ near the Strait of Gibraltar to $1.2 \%$ in the Balearic Islands owing to mixing with the isotopically heavier MOW and the local excess of evaporation over precipitation [Pierre, 1999]. Salinity also increases along this pathway. This isotopic and salinity increase should have been greater during the last glaciation because the east-west Mediterranean oxygen isotope gradient was greater because of reduced water exchange with the Atlantic and a more negative hydrologic budget [Rohling and De Rijk, 1999].

[29] The small negative anomalies in deep waters (i.e., $\delta^{18} \mathrm{O} C$. pachydermus data) compared to the pronounced depletions in ${ }^{18} \mathrm{O}$ of surface waters (i.e., $\delta^{18} \mathrm{O}$ G. bulloides data) during HE indicate that oxygen isotope and probably salinity gradients between MAW and WMDW ought to be very large. These large contrasts in salinity and density between the inflow and outflow waters could have resulted in decreased water mass mixing that allowed Atlantic surface waters with low $\delta^{18} \mathrm{O}$ to flow well into the Mediterranean without loosing its isotopic signature. Anyway, the small benthic $\delta^{18} \mathrm{O}$ depletions during the $\mathrm{HE}$ indicate that at least the entire western Mediterranean was affected by iceberg melting in the North Atlantic and the subsequent modification of inflow waters through the Strait of Gibraltar.

\subsection{Impact of North Atlantic Icebergs on Mediterranean Thermohaline Circulation}

[30] The $\delta^{13} \mathrm{C}$ values of Mediterranean deep water, as well as other biogeochemical parameters, are regulated by the strength of deepwater formation in the Gulf of Lions, the flux of organic carbon to the seafloor, and the rate of water exchange with the Atlantic [Béthoux et al., 1998; Pierre, 1999; Gómez, 2003]. Slower rates of deepwater convection and/or higher export productions would lead to decreasing values of $\delta^{13} \mathrm{C}$ in bottom waters [Pierre, 1999]. In contrast, higher $\delta^{13} \mathrm{C}$ values should be recorded at times of vigorous deepwater convection or lower carbon export. Of these two 
factors, the strength of Mediterranean deepwater formation probably contributed more to the $\delta^{13} \mathrm{C}$ variability, because surface productivity and export production are relatively low in the Mediterranean [Béthoux et al., 1998; Gómez, 2003].

[31] The small gradient existing today between the MAW $\left(\delta^{13} \mathrm{C}\right.$ values around $1.3 \%{ }_{0}-1.4 \%$ ) and the intermediate and deep Mediterranean waters of the western basin $(1 \%)$ is due to the intense formation of deep water in the Gulf of Lions that balances the ${ }^{13} \mathrm{C}$ depletion due to the regeneration of organic carbon exported from the surface [Pierre, 1999].

[32] During the last glacial period, the $C$. pachydermus $\delta^{13} \mathrm{C}$ record (Figure 3) reveals that the carbon isotope composition of deep Mediterranean waters changed in response to stadial (high $\delta^{13} \mathrm{C}$ )-interstadial (low $\delta^{13} \mathrm{C}$ ) oscillations (Figure 3). With the exception of the HE, these results corroborate the data reported by Cacho et al. [2000], indicating that Mediterranean deep convective overturning was very sensitive to climatic variability in the northeastern Atlantic, as evidenced by the striking parallelism between the Mediterranean benthic $\delta^{13} \mathrm{C}$ signal and the $\delta^{18} \mathrm{O}$ record from Greenland. Within Dansgaard-Oeschger stadials, reduced deepwater overturn cooled the North Atlantic and decreased the temperature and moisture content of air masses reaching the coast of southern Europe [Cacho et al., 2000; Sánchez-Goñi et al., 2002]. The combination of low SST [Cacho et al., 1999], cold northwesterly winds, and dry cool conditions prevailing on land [SánchezGoñi et al., 2002; Combourieu-Nebout et al., 2002] resulted in enhanced themohaline circulation in the Mediterranean with a concomitant increase in salt export to the Atlantic.

[33] In contrast, the warmer conditions throughout the eastern North Atlantic during the interstadials contributed to a faster transfer of heat and moisture to the atmosphere and, as a result, to increasing annual rainfall and warmer temperatures in southern Europe, as has been reported by Cacho et al. [2000] and Sánchez-Goñi et al. [2002]. The less negative hydrologic budget, together with less intense and more temperate winds, reduced Mediterranean thermohaline circulation. Our isotope record demonstrates that rapid reductions in Mediterranean overturn accompanied each of the abrupt warming events in Greenland (Figure 3).

[34] Alkenone, foraminifera and pollen records show that Mediterranean climate was cool and dry at times of HE [Cacho et al., 1999; Shackleton et al., 2000; Sánchez-Goñi et al., 2002; Combourieu-Nebout et al., 2002; de Abreu et al., 2003; Schönfeld et al., 2003; Pérez-Folgado et al., 2003]. These conditions should have led to an increase in the density of surface waters and, as a result, to an intensification of the Mediterranean thermohaline circulation during HE. This seems to be the case for the early and late phases of HE. However, strong depletions in $C$. pachydermus ${ }^{13} \mathrm{C}$ occurred during the middle of these events. These periods of more negative $\delta^{13} \mathrm{C}$ values of $C$. pachydermus suggest reduced deepwater formation and longer residence time for deep waters in the Mediterranean. Only salinity control of surface water density in the Gulf of Lions can explain the decrease in deepwater formation

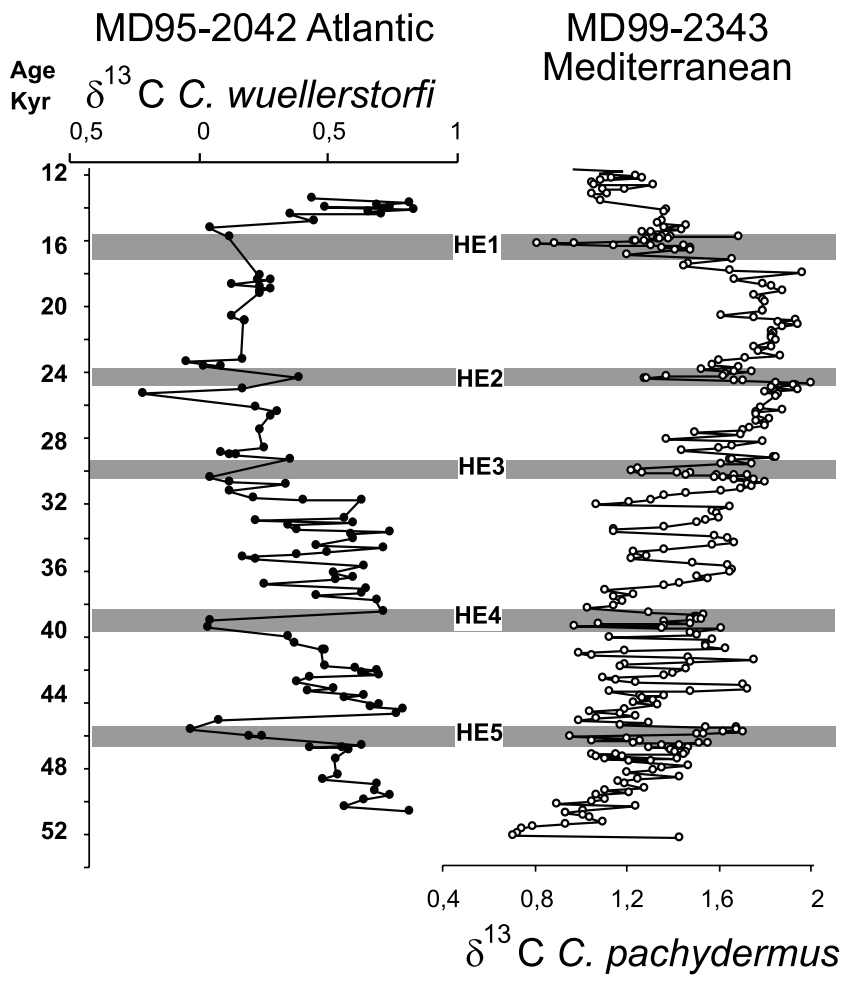

Figure 7. Comparison of $\delta^{13} \mathrm{C}$ records of Cibicidoides pachydermus in the Mediterranean (core MD99-2343) and the $\delta^{13} \mathrm{C}$ of Cibicidoides wuellerstorf $i$ in core MD95-2042 located along the Portuguese margin near the Strait of Gibraltar [Shackleton et al., 2000].

because temperatures were cold on both land and sea during HE [Cacho et al., 1999; Sánchez-Goñi et al., 2002; PérezFolgado et al., 2003]. ${ }^{13} \mathrm{C}$ depletions coincide with increases in the abundance of the polar species N. pachyderma (s) further indicating that temperature did not increase and reduce surface density. Since lower salinities are at odds with the more negative freshwater budget, it must be concluded that a large volume of freshwater carried by icebergs or meltwater-influenced surface waters would have entered the Mediterranean at times of HE, causing a decrease in sea surface salinity of a magnitude sufficient to strongly reduce the Mediterranean thermohaline circulation.

[35] By examining the carbon and oxygen isotope trends within each of the HE in detail (Figures 4 and 5), the mechanisms responsible for the changes in Mediterranean thermohaline circulation and their relationship to climatic change in the North Atlantic may be identified. In the early phase of the $\mathrm{HE}$, deepwater $\delta^{13} \mathrm{C}$ and surface water $\delta^{18} \mathrm{O}$ values increase, reflecting lower SSTs and higher salinities at the surface and enhanced deepwater overturning associated with coolings in Greenland. Deepwater convection in the Mediterranean was strong because of the high surface salinities and cold SST linked to the cold, dry climate in the circum-Mediterranean. However, in the middle of the HE, the entry of icebergs and/or meltwater derived from Atlantic 
icebergs reduced the oxygen isotope composition and salinity of surface waters, causing a slowdown of deepwater convection in the Gulf of Lions. The input of meltwater must have been large enough to compensate the otherwise high surface water densities derived from cold SSTs and low rainfall and runoff from the continents during such times [Cacho et al., 1999; Sánchez-Goñi et al., 2002; Combourieu-Nebout et al., 2002; Bartov et al., 2003]. All these events of reduced Mediterranean thermohaline circulation lasted less than 1000 years. Toward the latter part of the HE, as the contribution of meltwater to the Mediterranean decreased, deep convection increased because cold winds and dry conditions still prevailed in the western Mediterranean, as indicated by the high $\delta^{18} \mathrm{O}$ and $\delta^{13} \mathrm{C}$ values. These conditions did not abate until the following interstadial, when local climate conditions increased SST and reduced salinity, resulting in lower rates of deepwater formation.

\subsection{Long-Term Changes in Atlantic and Mediterranean Thermohaline Circulation Throughout the Last Glacial Period}

[36] The most positive benthic $\delta^{13} \mathrm{C}$ values in the Mediterranean occurred during the Last Glacial Maximum (LGM) (Figure 7), when the lowered sea level reduced water exchange with the Atlantic through the Strait of Gibraltar. Increased residence time of deep Mediterranean waters should have led to depleted $\delta^{13} \mathrm{C}$ values instead of the high values observed. Furthermore, the rate of organic carbon flux to the seafloor was high in the glacial, as inferred from the abundance of benthic foraminifera [Reguera, 2004], but not high enough to deplete the $\delta^{13} \mathrm{C}$ of the newly formed deep waters. Comparison of the long-term trends of the benthic $\delta^{13} \mathrm{C}$ record from core MD99-2042 [Shackleton et al., 2000] in the North Atlantic with our C. pachydermus $\delta^{13} \mathrm{C}$ record from core MD99-2343 shows that, except for the brief events described in this study, the ventilations of the deep North Atlantic and Mediterranean were anticorrelated for the last 52,000 years (Figure 7).

[37] From 52 to $19 \mathrm{kyr}$, as ice sheets expanded in the Northern Hemisphere, the deep Mediterranean became progressively better ventilated, whereas the influence of NADW was progressively reduced and replaced by Southern Ocean water [Duplessy et al., 1988; Sarnthein et al., 1994]. This is clearly reflected by the increasing $\delta^{13} \mathrm{C}$ values in the Mediterranean and decreasing $\delta^{13} \mathrm{C}$ values in the deep Atlantic (Figure 7). However, the records are punctuated by prominent excursions of opposite sign. Bond cycles are well defined in the $\delta^{13} \mathrm{C}$ records, but the isotope trends are opposite in the Atlantic $\left(\delta^{13} \mathrm{C}\right.$ decrease $)$ and the Mediterranean $\left({ }^{13} \mathrm{C}\right.$ increase) from bottom to top in each Bond cycle (Figure 7). The rate of deepwater formation reached the highest level in the Mediterranean at the LGM, especially between 27 and $19 \mathrm{kyr}$ (Figure 7), when the contribution of NADW was at a minimum and Antarctic Bottom Water (AABW) at a maximum [Duplessy et al., 1988; Sarnthein et al., 1994]. The increasing size and southward expansion of the northern ice sheets during the LGM, together with the increased freshwater flux to the ocean probably resulted in slower deepwater formation in the North Atlantic [Duplessy et al., 1988], but favored the southward expansion of cold polar winds that promoted deepwater convection along the northern coast of the Mediterranean (Gulf of Lions) as demonstrated in this study [see also Cacho et al., 2000].

[38] Another mechanism that may explain the AtlanticMediterranean anticorrelation in deep circulation is related to the reduced effect of temperature on the density of seawater at low temperatures. SSTs in the Mediterranean probably varied between $7^{\circ}$ and $10^{\circ} \mathrm{C}$ during the last glacial period [Cacho et al., 1999; Pérez-Folgado et al., 2003], while North Atlantic SSTs were close to freezing point [CLIMAP Project Members, 1976]. Whereas winter cooling in the Mediterranean would have increased surface water density and destabilized water column stratification, a similar cooling in the Atlantic would have had a relatively small effect on surface density because of its cold SST. Consequently, a colder temperature in the Atlantic was unable to overcome the salinity-controlled density gradients in the North Atlantic [Sigman et al., 2004], whereas it severely changed surface density in the Mediterranean. As a result, the Mediterranean could have been operating in phase with $\mathrm{AABW}$ formation, injecting salty and $\delta^{13} \mathrm{C}$ enriched waters to the Atlantic at times of lower NADW production.

\section{Conclusions}

[39] Comparison of the oxygen and carbon isotope records from core MD99-2343 in the northwestern Mediterranean with isotope records from the northeast Atlantic and the Greenland Ice Core (GISP2) has allowed us to elucidate the relationship between deep thermohaline circulations in the Atlantic and Mediterranean for the past 52,000 years. Lower G. bulloides $\delta^{18} \mathrm{O}$ and C. pachydermus $\delta^{13} \mathrm{C}$ values during interstadial events indicate warmer surface waters in the Mediterranean, and reduced rates of deepwater convection in response to the transfer of heat and moisture to western Europe during times of enhanced NADW formation. In contrast, increase in oxygen and carbon isotope values during stadial events were the result of cold temperatures and dry terrestrial climate conditions that enhanced deepwater formation in the Mediterranean during times of reduced NADW production. Because temperature variability in Greenland was mainly regulated by North Atlantic thermohaline circulation and the associated rates of northward heat advection, we conclude that deepwater circulation in the deep Atlantic and Mediterranean were generally anticorrelated during the stadial-interstadial events of the last glacial period. An exception to this relationship occurred during the middle part of the HE, when thermohaline circulation in both the deep Mediterranean and Atlantic was reduced. At these times, brief yet pronounced negative isotope anomalies occurred in the G. bulloides $\delta^{18} \mathrm{O}$ and C. pachydermus $\delta^{13} \mathrm{C}$ records, coinciding with large increases in the abundance of the polar species N. pachyderma (s) and the cold water coccolithophorid E. huxleyi $(>4 \mu \mathrm{m})$. Cold temperatures and arid climate dominated during the middle of the HE which should have been a time 
of high salinity and high density of Mediterranean surface waters. As low salinities are not predicted during times of cold, dry climate, an external freshwater source is needed to explain the decrease in Mediterranean planktonic $\delta^{18} \mathrm{O}$ and sea surface salinity. We conclude that North Atlantic icebergs or the meltwater derived from them entered the Mediterranean. The effect was to reduce surface salinity and deepwater formation in the Mediterranean, similar to the impact meltwater had on reducing rates of NADW formation. Heinrich events represent the only time during stadial-interstadial events of the last glacial period when both the deep North Atlantic and Mediterranean thermohaline circulation was simultaneously reduced.

[40] Acknowledgments. We are especially grateful to the Institut Francais de Recherche Polaire for funding and operational support of the IMAGES program and the Marion Dufresne Cruise MD99 during which core MD99-2343 and MD95-2043 were collected. This work was funded by MECD and MCYT grants BTE2002-04670, REN2003-08642-C02/CLI, European Project PROMESS1, and ABRUMED. The reviews by K. N. Jansson and C. Rühlemann greatly improved an earlier version of the manuscript. Thanks are due to José Gravalosa and Jesús Roncero for technical assistance in sample processing and foraminifera picking for isotopic analyses.

\section{References}

Bard, E., F. Rostek, J. L. Turon, and S. Gendreau (2000), Hydrological impact of Heinrich events in the subtropical northeast Atlantic, Science, 289, 1321-1324.

Bartov, Y., S. L. Goldstein, M. Stein, and Y. Enzel (2003), Catastrophic arid episodes in the eastern Mediterranean linked with the North Atlantic Heinrich events, Geology, 31, 439-442.

Béthoux, J. P., P. Morin, C. Chaumery, O. Connan, B. Gentili, and D. Ruiz-Pino (1998), Nutrients in the Mediterranean Sea, mass balance and statistical analysis of concentrations with respect to environmental change, Mar. Chem., 63, $155-169$

Bond, G. C., and R. Lotti (1995), Iceberg discharges into the North Atlantic on millennial time scales during the last glaciation, Science, $267,1005-1010$.

Bond, G., et al. (1992), Evidence for massive discharges of icebergs into the glacial northern Atlantic, Nature, 360, 245-249.

Bond, G., W. Broecker, S. Johnsen, J. McManus, L. Labeyrie, J. Jouzel, and G. Bonani (1993), Correlations between climate records from North Atlantic sediments and Greenland ice, Nature, 365, 143-147.

Broecker, W. S., D. Peteet, and D. Rind (1985), Does the ocean-atmosphere system have more than one stable mode of operation?, Nature, $315,21-25$.

Broecker, W. S., G. Bond, J. F. McManus, M. Klas, and E. Clark (1992), Origin of the northern Atlantic's Heinrich events, Clim. Dyn., 6, 265273.

Bryden, H. L., J. Candela, and T. H. Kinder (1994), Exchange through the Strait of Gibraltar, Prog. Oceanogr., 33, 201-248.

Cacho, I., J. O. Grimalt, C. Pelejero, M. Canals, F. J. Sierro, J. A. Flores, and N. J. Shackleton (1999), Dansgaard-Oeschger and Heinrich event imprints in the Alboran Sea paleotemperatures, Paleoceanography, 14, 698-705.

Cacho, I., J. O. Grimalt, F. J. Sierro, N. J. Shackleton, and M. Canals (2000), Evidence for enhanced Mediterranean thermohaline circulation during rapid climatic coolings, Earth Planet. Sci. Lett., 183, 417-429.

CLIMAP Project Members, (1976), The surface of the Ice-Age Earth, Science, 191, 1131-1137.

Colmenero-Hidalgo, E., J. A. Flores, and F. J. Sierro (2002), Biometry of Emiliana huxleyi and its biostratigraphic significance in the eastern North Atlantic Ocean and western Mediterranean Sea in the last 20,000 years, Mar. Micropaleontol., 46, 247-263.

Colmenero-Hidalgo, E., J. A. Flores, F. J. Sierro, M. A. Bárcena, L. Löwemark, J. Schönfeld, and J. O. Grimalt (2004), Ocean surface water response to short-term climate changes revealed by coccolithophores from the Gulf of Cadiz (NE Atlantic) and Alboran Sea (W Mediterranean), Palaeogeogr. Palaeoclimatol. Palaeoecol., 205, 317-336.

Comas, M. C., et al. (1996), Proceedings of the Ocean Drilling Program Initial Reports, vol. 161, 1023 pp., Ocean Drill. Program, College Station, Tex.

Combourieu-Nebout, N., J. L. Turon, R. Zahn, L. Capotondi, L. Londeix, and K. Pahnke (2002), Enhanced aridity and atmospheric high-pressure stability over the western Mediterranean during the North Atlantic cold events of the past 50 k.y., Geology, 30, 863-866.

Coplen, T. B. (1996), New guidelines for the reporting of stable hydrogen, carbon, and oxygen isotope ratio data, Geochim. Cosmochim. Acta, 60, 3359-3360.

Cortijo, E., L. Labeyrie, L. Vidal, M. Vautravers, M. Chapman, J. C. Duplessy, M. Elliot, M. Arnold, J. L. Turon, and G. Auffret (1997) Changes in sea surface hydrology associated with Heinrich event 4 in the North Atlantic Ocean between $40^{\circ}$ and $60^{\circ} \mathrm{N}$, Earth Planet Sci. Lett., 146, 29-45.

Craig, H., and L. I. Gordon (1965), Isotopic oceanography: Deuterium and oxygen 18 variation in the ocean and the marine atmosphere, in Stable Isotopes in Oceanographic Studies and Paleotemperatures, edited by E. Tongiorgi, pp. 9-130, Cons. Naz. di Rech., Spoleto, Italy.

Dansgaard, W., et al. (1993), Evidence for general instability of past climate from 250-ka ice-core record, Nature, 364, 218 220.

de Abreu, L., N. J. Shackleton, J. Schönfeld, M. Hall, and M. Chapman (2003), Millennialscale oceanic climate variability off the western Iberian margin during the last two glacial periods, Mar. Geol., 196, 1-20.

Duplessy, J. C., N. J. Shackleton, R. G. Fairbanks, L. Labeyrie, D. Oppo, and N. Kallel (1988) Deepwater source variations during the last climatic cycle and their impact on the global deepwater circulation, Paleoceanography, 3 , $343-360$.

Elliot, M., L. Labeyrie, G. Bond, E. Cortijo, J. L. Turon, N. Tisnerat, and J. C. Duplessy (1998), Millennial-scale iceberg discharges in the Irminger Basin during the last glacial period: Relationship with the Heinrich events and environmental settings, Paleoceanography, $13,433-446$.

Elliot, M., L. Labeyrie, T. Dokken, and S. Manthe (2001), Coherent patterns of ice-rafted debris deposits in the Nordic regions during the last glacial (10-60 ka), Earth Planet. Sci. Lett., 194, 151-163.
Elliot, M., L. Labeyrie, and J. C. Duplessy (2002), Changes in North Atlantic deep-water formation associated with the DansgaardOeschger temperature oscillations (60$10 \mathrm{Ka})$, Quat. Sci. Rev., 21, 1153-1165.

Flores, J. A., and F. J. Sierro (1997), Revised technique for calculation of calcareous nannofossil accumulation rates, Micropaleontology, 43, 321-324.

Genti, D., D. Blamart, R. Ouhdi, M. Gilmour, A. Baker, J. Jouzel, and S. Van-Exter (2003), Precise dating of Dansgaard-Oeschger climate oscillations in Western Europe from stalagmite data, Nature, 421, 833-837.

Gómez, F. (2003), The role of the exchanges through the Strait of Gibraltar on the budget of elements in the western Mediterranean Sea: Consequences of human-induced modifications, Mar. Pollut. Bull., 46, 685-694.

Grootes, P. M., and M. Stuiver (1997), Oxygen 18/16 variability in Greenland snow and ice with 103 to 105 -year time resolution, J. Geophys. Res., 102, 26,455-26,470.

Grousset, P. E., L. Labeyrie, J. A. Sinko, M. Cremer, G. Bond, J. Duprat, E. Cortijo, and S. Huon (1993), Patterns of ice-rafted detritus in the glacial North Atlantic (40$\left.55^{\circ} \mathrm{N}\right)$, Paleoceanography, 8, 175-192.

Grousset, P. E., C. Pujol, L. Labeyrie, G. Auffret, and A. Boelaert (2000), Were the North Atlantic Heinrich events triggered by the behaviour of the European ice sheets?, Geology, 28, 123-126.

Heinrich, H. (1988), Origin and consequences of cyclic ice rafting in the northeast Atlantic Ocean during the past 130,000 years, Quat Res., 29, 143-152.

Hilgen, F. J. (1991), Astronomical calibration of Gauss to Matuyama sapropels in the Mediterranean and implication for the geomagnetic polarity timescale, Earth Planet. Sci. Lett., 104, 226-244.

Johnson, R. G. (1997), Climate control requires a dam at the Strait of Gibraltar, Eos Trans. AGU, $78(27), 277,280-281$

Kim, S. T., and J. R. O'Neil (1997), Equilibrium and nonequilibrium oxygen isotope effects in synthetic calcites, Geochim. Cosmochim. Acta, 61, 3461-3475.

Lacombe, H., P. Tchernia, and L. Gamberoni (1985), Variable bottom water in the western Mediterranean basin, Prog. Oceanogr., 14 319-338.

Lea, D. W., P. A. Martina, D. K. Paka, and H. J. Spero (2002), Reconstructing a 350 ky history of sea level using planktonic $\mathrm{Mg} / \mathrm{Ca}$ and oxygen isotope records from a Cocos Ridge core, Quat. Sci. Rev., 21, 283-293.

Mangerud, J., M. H. Jakobsson, H. Alexanderson, V. Astakhov, G. K. C. Clarke, M. Henriksen, 
C. Hjort, G. Krinner, J. P. Lunkka, and P. Moller (2004), Ice-dammed lakes and rerouting of the drainage of northern Eurasia during the last glaciation, Quat. Sci. Rev., 23, $1313-1332$.

Martrat, M., J. O. Grimalt, C. López-Martínez, I. Cacho, F. J. Sierro, J. A. Flores, R. Zahn, M. Canals, J. H. Curtis, and D. A. Hodell (2004), Abrupt temperature changes in the western Mediterranean during the last and penultimate glacial and interglacial periods, Science, 306, 1762-1765.

MEDOC Group (1970), Observation of formation of deep water in the Mediterranean Sea, Nature, 227, 1037-1040.

Meese, D. A., A. J. Gow, R. B. Alley, P. M. Zielinski, G. A. Grootes, M. Ram, K. C. Taylor, P. A. Mayewski, and J. F. Bolzan (1997), The Greenland Ice Sheet Project 2 depth-age scale: Methods and results, J. Geophys. Res., 102, 26,411-26,423.

Millot, C. (1999), Circulation in the western Mediterranean Sea, J. Mar. Syst., 20, 423-442.

Mulder, T. et al. (2002), Past deep-water circulation and the paleoclimate record: Gulf of Cadiz, Eos Trans. AGU, 83(43), 481, 478-488.

Pérez-Folgado, M., F. J. Sierro, J. A. Flores, I. Cacho, J. O. Grimalt, R. Zahn, and N. Shackleton (2003), Western Mediterranean planktonic foraminifera events and millennial climatic variability during the last 70 kyr, Mar. Micropaleontol., 48, 49-70.

Pierre, C. (1999), The oxygen and carbon isotope distribution in the Mediterranean water masses, Mar. Geol., 153, 41-45.

Rahmstorf, S. (1998), Influence of Mediterranean outflow on climate, Eos Trans. $A G U$, 79(24), 281-282.

Reguera, I. (2004), Respuesta del Mediterráneo occidental a los cambios bruscos ocurridos durante el último ciclo glacial: Estudio de las asociaciones de foraminíferos, Ph.D. thesis, 231 pp., Univ. de Salamanca, Salamanca, Spain.

Reid, J. L. (1979), On the contribution of the Mediterranean Sea outflow to the Norwegian-
Greenland Sea, Deep Sea Res., Part A, 26, 1199-1223.

Rohling, E. J. (1994), Review and new aspects concerning the formation of eastern Mediterranean sapropels, Mar. Geol., 122, 1-28.

Rohling, E. J. (1999), Environmental control on Mediterranean salinity and $\delta^{18} \mathrm{O}$, Paleoceanography, 14, 706-715.

Rohling, E. J., and S. De Rijk (1999), Holocene climate optimum and Last Glacial Maximum in the Mediterranean: The marine oxygen isotope record, Mar. Geol., 153, 57-75.

Rossignol-Strick, M., V. Nesteroff, P. Olive, and C. Vergnaud-Grazzini (1982), After the deluge: Mediterranean stagnation and sapropel formation, Nature, 295, 105-110.

Ruddiman, W. F. (1977), Late Quaternary deposition of ice rafted sand in the subsolar North Atlantic, Geol. Soc. Am. Bull., 83, 2817-2836.

Sánchez-Goñi, M. F., I. Cacho, J. L. Turon, J. Guiot, F. J. Sierro, J. P. Peypouquet, J. O. Grimalt, and N. J. Shackleton (2002), Synchroneity between marine and terrestrial responses to millennial scale climatic variability during the last glacial period in the Mediterranean region, Clim. Dyn., 19, 95-105.

Sarnthein, M., K. Winn, J. J. A. Jung, J. C. Duplessy, L. Labeyrie, H. Erlenkeuser, and G. Ganssen (1994), Changes in east Atlantic deepwater circulation over the last 30,000 years: Eight time slice reconstructions, Paleoceanography, 9, 209-267.

Schönfeld, J., and R. Zahn (2000), Late glacial to Holocene history of the Mediterranean Outflow: Evidence from benthic foraminiferal assemblages and stable isotopes at the Portuguese margin, Palaeogeogr. Palaeoclimatol. Palaeoecol, 159, 85-111.

Schönfeld, J., R. Zahn, and L. De Abreu (2003), Surface and deep water response to rapid climate changes at the Western Iberian Margin, Global Planet. Change, 36, 237-264.

Shackleton, N. J., M. A. Hall, and E. Vincent (2000), Phase relationships between millennial-scale events 64,000-24,000 years ago, Paleoceanography, 15, 565-569.
Sigman, D. M., S. L. Jaccard, and G. H. Haug (2004), Polar ocean stratification in a cold climate, Nature, 428, 59-63.

Skinner, L. C., and N. J. Shackleton (2003), Millennial-scale variability of deep-water temperature and $\delta^{18} \mathrm{O}_{\mathrm{dw}}$ indicating deep-water source variations in the northeast Atlantic, $0-34 \mathrm{cal}$. ka BP, Geochem. Geophys. Geosyst., 4(12), 1098, doi:10.1029/2003GC000585.

Stuiver, M., P. J. Reimer, E. Bard, J. W. Beck, G. S. Burr, K. A. Hughen, B. Kromer, F. G. McCormac, J. v. d. Plicht, and M. Spurk (1998), INTCAL98 radiocarbon age calibration 24,000-0 cal BP, Radiocarbon, 40, $1041-1083$.

Velasco, J. P. B., J. Baraza, M. Canals, and J. Balón (1996), La depresión periférica y el lomo contourítico de Menorca: Evidencias de la actividad de corrientes de fondo al $\mathrm{N}$ del talud Balear, Geogaceta, 20, 95-98.

Vidal, L., L. Labeyrie, E. Cortijo, M. Arnold, J. C. Duplessy, E. Michel, S. Becqué, and T. C. E. van Weering (1997), Evidence for changes in the North Atlantic Deep Water linked to meltwater surges during the Heinrich events, Earth Planet. Sci. Lett., 146, 13-27.

M. A. Bárcena, E. Colmenero-Hidalgo, J. A. Flores, I. Reguera, and F. J. Sierro, Department of Geology, University of Salamanca, Plaza de la Merced s/n. 37008, Salamanca, Spain. (sierro@ usal.es)

I. Cacho, M. Canals, and J. Frigola, Department of Stratigraphy, Paleontology and Marine Geosciences, Campus de Pedralbes, University of Barcelona, 08028 Barcelona, Spain.

J. H. Curtis and D. A. Hodell, Department of Geological Sciences, University of Florida, Gainesville, FL 32611-2120, USA.

J. O. Grimalt, Department of Environmental Chemistry, Institute of Chemical and Environmental Research (CSIC), Jordi Girona, 18, 08034, Barcelona, Spain. 